\title{
Communication
}

\section{Phenoxypropylamines: Synthesis and Antiulcer Evaluation}

\section{Hui Zhang ${ }^{1,2, *}$, Bao-Yan Zhang ${ }^{1}$, Qian-Yun Zhang ${ }^{3}$, Dong-Mei Zhao ${ }^{4}$ and Jia-Mei Wang ${ }^{5}$}

1 College of Sciences, Northeastern University, Shenyang 110004, China;

E-mail: baoyanzhang2005@126.com (B-Y.Z.)

2 Department of Chemistry, Shenyang Medical College, Shenyang 110034, China;

3 School of Public Health, China Medical University, Shenyang 110001, China; E-mail: iamxiaoqian@126.com (Q-Y.Z.)

4 School of Pharmaceutical Engineering, Shenyang Pharmaceutical University, Shenyang 110016, China; E-mail: dongmeiz-67@163.com (D-M.Z.)

5 School of Medicinal Application \& Technology, Shenyang Medical College, Shenyang 110034, China; E-mail: jinxing19890104@126.com (J-M.W.)

* Author to whom correspondence should be addressed; E-mail: a13998826073@163.com; Tel.: +8624-62215448; Fax: +86-24-62215656

Received: 9 April 2009 in revised form: 4 May 2009 / Accepted: 08 May 2009 / Published: 13 May 2009

\begin{abstract}
We have synthesized a number of phenoxypropylamines from $\mathrm{N}-\{3-[3-(1-$ piperidinylmethyl)phenoxy]propyl $\}$ chloroacetamide (3). All the products have been characterized by elemental analysis, ${ }^{1} \mathrm{H}-\mathrm{NMR}$ and MS. The biological activity effects of the title compounds were examined. From the biological activity results, we found that two of them showed significant gastric acid antisecretory activity.
\end{abstract}

Keywords: roxatidine; synthesis; antiulcer agents; phenoxypropylamine; biological activity

\section{Introduction}

The introduction of roxatidine acetate (4) as a $\mathrm{H}_{2}$-receptor antagonist for the control of peptic ulcer disease has been responsible for intense synthetic efforts by medicinal chemists in this therapeutic area to prepare highly efficacious drugs with greater potency and lower toxicity [1]. 
As part of our effort to explore a new antiulcer agent, this work was initiated with the goal of preparing a new compound which might possess potent gastric acid antisecretory and gastrointestinal protective activities with lower toxicity. In this paper we describe the preparation and antiulcer activity of compounds 6a-6f. Roxatidine acetate (4) was synthesized by a series of reaction including Leukart reductive amination, acylation and substitution [2]. On the basis of the bioisosterism principle phenoxypropylamines were prepared from compound 3 using primary amines [3]. The process is simple and moderate. The desired products were synthesized and identified on the basis of elemental analysis, ${ }^{1} \mathrm{H}-\mathrm{NMR}$ and MS. The title compounds 6a-6f were also been evaluated for gastric acid antisecretory activity and the structure activity relationships of gastric acid antisecretory activity are also discussed.

\section{Results and Discussion}

$N$-\{3-[3-(1-Piperidinymethyl)phenoxy]propyl\} chloroacetamide (3) was synthesized by a three-step reaction from $m$-hydroxybenzaldehyde. The hydrochloric acid salt of roxatidine acetic ester 4 was prepared in $28.8 \%$ yield by the reaction of 3 with AcOK [2]. Six phenoxypropylamine derivatives were then synthesized by the reaction of 3 with primary amines, followed by oxalic acid to obtain their corresponding salts 6 . The synthesis route is outlined in Scheme 1.

Scheme 1. Synthesis of the title compounds 6a-6f.

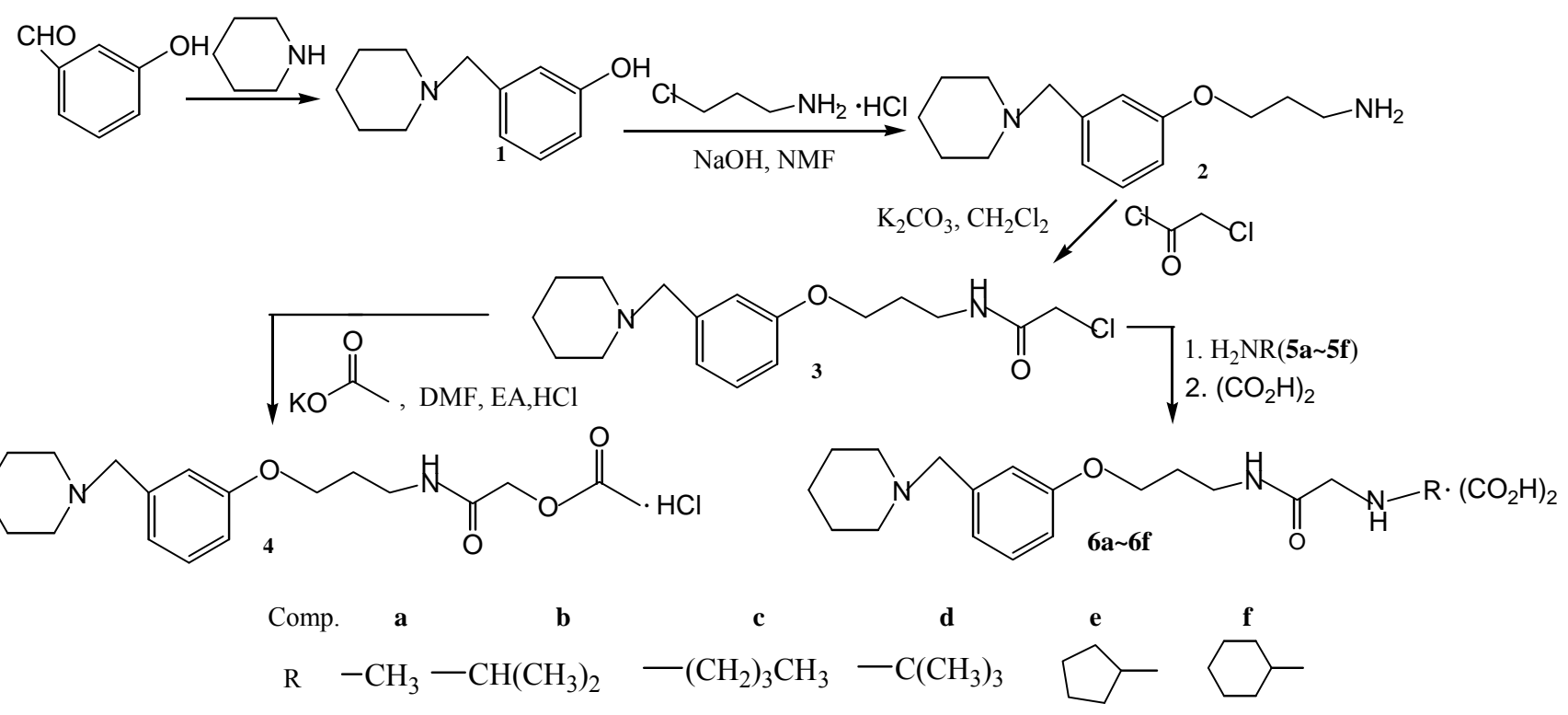

Biological evaluation [4,5]

The effects of the title compounds 6a-6f on gastric acid secretion are shown in Figure 1. The percentages of inhibition of gastric juice, GJ, 98.1\%, 91.1\%, 47.5\%, 60.2\%, 88.3\% and 61.2\%, respectively. As seen in the Figure, compounds $6 \mathbf{6}$ and $\mathbf{6 f}$ exhibited significant gastric acid antisecretory activity. That this gastric acid antisecretion efficacy was based on $\mathrm{H}_{2}$-receptor antagonist properties was confirmed by using the isolated guinea pig right atrial assay [7]. 
Figure 1. Phenoxypropylamine Effect on Gastric Acid Secretion in the Isolated Guinea Pig.

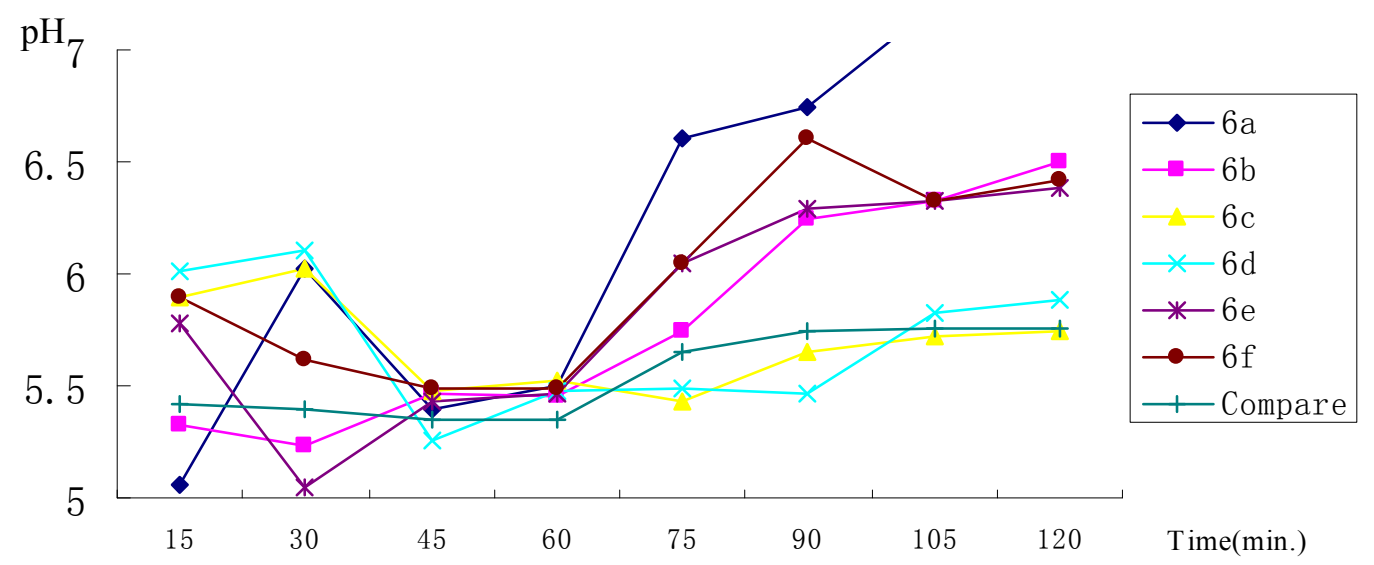

The calculation methods used In Figure 1 were as follows:

$$
\begin{aligned}
& \text { Acid output, } \mathrm{AO}=\left[\mathrm{H}^{+}\right] \times 0.05 /\left(\pi \times 1.25^{2} \times 0.25\right) \mathrm{mol} \cdot \mathrm{cm}^{-2} \cdot \mathrm{h}^{-1} \\
& =10^{-\mathrm{pH}} \times 4 \times 10^{-2} \mathrm{~mol} \cdot \mathrm{cm}^{-2} \cdot \mathrm{h}^{-1} \\
& =10^{-\mathrm{pH}} \times 4 \times 10^{4} \mu \mathrm{mol} \cdot \mathrm{cm}^{-2} \cdot \mathrm{h}^{-1} \\
& \mathrm{GJ}=(\text { Basic acid output, } \mathrm{BAO}-\mathrm{AO}) / \mathrm{BAO} \times 100 \%
\end{aligned}
$$

With regards to possible SAR, our preliminary assumption was to synthesize the compounds 6a and 6b by adding primary amine straight chains in order to enhance the ability of the molecules to inhibit gastric acid. We synthesized compounds $\mathbf{6 c}$ and $\mathbf{6 d}$ by adding a branched chain primary amine in order to enhance the flexibility of the molecules. The compounds $\mathbf{6 e}$ and $\mathbf{6 f}$ are the $\mathrm{H}_{2}$-receptor antagonists.

\section{Conclusions}

In summary, we have developed the method for preparing phenoxypropylamine derivatives of roxatidine acetate from $\mathrm{N}$-\{3-[3-(1-piperidinylmethyl)phenoxy]propyl $\}$ chloroacetamide. The protocol offers several advantages such as mild reaction conditions, short reaction times, easy isolation and good yields. Also two of them showed some potential effects on the inhibition of gastric juice.

\section{Experimental}

\section{General}

Melting points for the compounds were determined on a hot-stage microscope and are uncorrected. IR spectra were determined on a Nicolet 670FT-IR instrument in the range $4000-400 \mathrm{~cm}^{-1}$ using the Smart OMNI-Sampler. ${ }^{1} \mathrm{H}-\mathrm{NMR}$ spectra were recorded in DMSO- $\mathrm{d}_{6}$ solution on a Bruker ARX-300 spectrometer operating at $300 \mathrm{MHz}$ with TMS as the internal reference. Coupling constants $(J)$ are expressed in Hz. MS spectra were obtianed using a Finnigan SSQ-710 spectrometer. The contents of carbon, hydrogen and nitrogen were determined on a Flash-1112 series elemental analyzer. Column chromatography was performed on silica gel (200-300 mesh) obtained from Qingdao Ocean Chemicals. Unless otherwise noted, all the materials were obtained from commercial sources and used without further purification. 
3-(1-Piperidinylmethyl)phenol (1): 3-Hydroxybenzaldehyde (30.6 g, $0.25 \mathrm{~mol})$ and $88 \%$ formic acid $(30.0 \mathrm{~mL}, 0.7 \mathrm{~mol})$ were successively added to piperidine $(50 \mathrm{~mL}, 0.5 \mathrm{~mol})$ in a cool bath while the temperature was kept below $60^{\circ} \mathrm{C}$. The mixture was then heated at $100^{\circ} \mathrm{C}$ for two hours and after cooling to $15^{\circ} \mathrm{C}$ it was diluted with water $(75 \mathrm{~mL})$. One gram of activated carbon was added and stirred for $1 \mathrm{~h}$ at room temperature for decolourizing. The carbon was filtered off, and the solution is made alkaline to $\mathrm{pH}=9.0$ by adding a $12 \%$ ammonium hydroxide solution. The product $\mathbf{1}$, which crystallizes on standing at $15^{\circ} \mathrm{C}$, was filtered and washed with water. When dried well the isolated compound 1 weighed $36.02 \mathrm{~g}$ (79.3\%); m.p. 136-138 ${ }^{\circ} \mathrm{C}$. IR (KBr): 2900, $3400 \mathrm{~cm}^{-1}$; MS m/z (\%): 191 $\left(\mathrm{M}^{+}, 18\right), 107$ (49), 84 (100); ${ }^{1} \mathrm{H}-\mathrm{NMR}: 1.41-1.42$ (d, 2H, $\left.J=5\right), 1.56-1.59$ (m, 4H, J=7), 2.43 (s, 4H), $3.41(\mathrm{~s}, 2 \mathrm{H}), 6.44(\mathrm{bs}, 1 \mathrm{H}), 6.66-6.70(\mathrm{~d}, 2 \mathrm{H}, J=8), 6.75-6.77(\mathrm{~d}, 1 \mathrm{H}, J=8), 7.08-7.13(\mathrm{t}, 1 \mathrm{H}, J=8)$ [2].

$N$-\{3-[3-(1-Piperidinylmethyl)phenoxy]propyl\}amine (2): 3-(1-Piperidinylmethyl)phenol (1, $9.6 \mathrm{~g}$, $0.05 \mathrm{~mol})$ and 3-chloropropylamine hydrochloride $(8.40 \mathrm{~g}, 0.064 \mathrm{~mol})$ were successively added to DMF $(160 \mathrm{~mL})$, then sodium hydroxide $(28.4 \mathrm{~g}, 0.71 \mathrm{~mol})$ was added. The reaction mixture is stirred at $85-90^{\circ} \mathrm{C}$ for two hours and filtered after cooling to $15^{\circ} \mathrm{C}$. Potassium acetate $(0.96 \mathrm{~g}, 0.01 \mathrm{~mol})$ was added, and about $20 \mathrm{~mL}$ of DMF were distilled off under vacuum. The residue is diluted with water $(40 \mathrm{~mL})$ acidified with acetic acid to $\mathrm{pH}=4.6$ and extracted with dichloromethane $(50 \mathrm{~mL})$. The aqueous layer is alkalinized to $\mathrm{pH}=9.5$ with $12 \%$ ammonium hydroxide solution, extracted twice with dichloromethane $(50 \mathrm{~mL})$, dried with sodium sulfate, and filtered. This solution contains $12.04 \mathrm{~g}$ (97\%) of 2 and is directly used in the next step without isolation. Oily substance; IR (film): 2925, 3300 $\mathrm{cm}^{-1}$; MS m/z (\%): 248 (M+, 7.46), 190 (2.81), 165 (10.49), 107 (8.84), 98 (24.76), 84 (100); ${ }^{1} \mathrm{H}-\mathrm{NMR}$ $\delta: 1.36$ (bs, 2H, $J=5), 1.41-1.43$ (d, 2H, $J=5), 1.53-1.60$ (m, 4H, $J=5), 1.87-1.96$ (m, 2H, J=7), 2.36 (s, $4 \mathrm{H}$ ), 2.89-2.92 (t, 2H, J=7), 3.43 (s, 2H), 4.02-4.06 (t, 2H, J=7), 6.75-6.79 (dd, $1 \mathrm{H}, J=8), 6.87-6.89$ $(\mathrm{d}, 2 \mathrm{H}, J=8), 7.17-7.22(\mathrm{t}, 1 \mathrm{H}, J=8)[2]$.

$N$-\{3-[3-(1-Piperidinylmethyl)phenoxy] propyl\}chloroacetamide (3): Dry potassium carbonate (11.3 g, $0.082 \mathrm{~mol})$ was added to dried dichloromethane $(100 \mathrm{~mL})$ containing compound $2(10.10 \mathrm{~g}, 0.04 \mathrm{~mol})$. The mixture is cooled to $0-5^{\circ} \mathrm{C}$, and chloroacetyl chloride $(5.99 \mathrm{~g}, 0.053 \mathrm{~mol})$ in dichloromethane $(10 \mathrm{~mL})$ were added. Thirty min later cold water $(10 \mathrm{~mL})$ was added, the organic layer washed twice with brine, dried, and filtered. The solvent is evaporated and the residue dried in vacuo to give $13.04 \mathrm{~g}$ (98.0\%) of 3 as a colorless, partially crystallized oily substance. IR (film): 1670, 2940, 3000, $3400 \mathrm{~cm}^{-1}$; MS m/z (\%): 324 (M+, 10), 240 (1.74), 190 (5.25), 134 (74.6), 84 (100); ${ }^{1}$ H-NMR: 1.41 $1.43(\mathrm{~d}, 2 \mathrm{H}, J=5), 1.53-1.60(\mathrm{~m}, 4 \mathrm{H}, J=5), 1.90(\mathrm{~s}, 1 \mathrm{H}), 2.01-2.09(\mathrm{~m}, 2 \mathrm{H}, J=7), 2.37$ (s, $4 \mathrm{H}), 3.44$ (s, 2H), 3.51-3.57 (m, 2H, J=7), 4.06 (s, 2H), 4.07-4.11 (t, 2H, J=7), 6.77-6.80 (dd, 1H, J=8), 6.90-6.92 $(\mathrm{d}, 2 \mathrm{H}, J=8), 7.19-7.24(\mathrm{t}, 1 \mathrm{H}, J=8)[2]$.

$N$-\{3-[3-(1-Piperidinylmethyl)phenoxy] propyl\}acetoxyacetamide hydrochloride (4): Chloroacetamide $3(1.07 \mathrm{~g}, 0.0033 \mathrm{~mol})$ is dissolved in DMF $(40 \mathrm{~mL})$, then dry potassium acetate $(1.97 \mathrm{~g}, 0.0099 \mathrm{~mol})$ was added. The mixture was stirred at $90-100^{\circ} \mathrm{C}$ for one hour, and most of DMF is distilled off under vacuum. The residue is evacuated at $40-50^{\circ} \mathrm{C}$. Water $(50 \mathrm{~mL})$ acidified with acetic acid to $\mathrm{pH}=4.6$ was added, and the solution is extracted with a portion of dichloromethane $(20 \mathrm{~mL})$. The acidic solution is 
decolourized with $1 \mathrm{~g}$ of activated carbon, alkalinized to $\mathrm{pH}=9.5$ with a $12 \%$ ammonium hydroxide solution and then extracted twice with ethyl acetate $(15 \mathrm{~mL})$, washed with brine, and dried over sodium sulfate. The organic solution is treated with ethyl acetate saturated with hydrogen chloride at $0-5^{\circ} \mathrm{C}$. The roxatidine acetate hydrochloride 4 separates as a white precipitate on cooling that agglomerates on standing. It is filtered and washed with dry ethyl acetate. After drying in vacuo $2.37 \mathrm{~g}$ $(6.8 \mathrm{mmol})$ of 4 of $85.13 \%$ purity are obtained. Roxatidine acetate hydrochloride (4): m.p. $148-150^{\circ} \mathrm{C}$; IR $\left(\mathrm{CHCl}_{3}\right): 1675,1755,3000,3430 \mathrm{~cm}^{-1} ;{ }^{1} \mathrm{H}-\mathrm{NMR}: 1.43-1.44$ (d, 2H, J=5), 1.53-1.58 (m, 4H, J=5), 2.00-2.08 (m, 2H, J=7), $2.14(\mathrm{~s}, 3 \mathrm{H}), 2.36(\mathrm{~s}, 4 \mathrm{H}), 3.43(\mathrm{~s}, 2 \mathrm{H}), 3.52-3.58(\mathrm{q}, 2 \mathrm{H}, J=7), 4.06-4.09$ (t, $2 \mathrm{H}, J=7), 4.56$ (s, 2H), 6.65 (bs, $1 \mathrm{H}), 6.77-6.80$ (dd, $1 \mathrm{H}, J=8), 6.91-6.92$ (d, 2H, J=8), 7.19-7.24 (t, 1H, $J=8$ ); Elemental anal. calcd. (\%): C, 59.37; H, 7.55; N, 7.29. Found (\%): C, 59.19; H, 7.86; N, 7.44; MS m/z (\%): 348 (M+12.37), 305 (2.57), 222 (5.04), 190 (9.40), 158 (62.63), 84 (100) [2].

\section{Preparation and analytical and spectral data for compounds $\mathbf{6 a} \mathbf{- 6 f}$}

$N$-\{3-[3-(1-Piperidinylmethyl)phenoxy]propyl $\}$ chloroacetamide (3, $0.0043 \mathrm{~mol})$ are dissolved in acetonitrile $(30 \mathrm{~mL})$, then the appropriate primary amine $(0.0086 \mathrm{~mol})$ and dry potassium iodide $(0.006 \mathrm{~g})$ are added, and the mixture is stirred at $90-100^{\circ} \mathrm{C}$ for four hours. Most of acetonitrile is then distilled off under vacuum. Water $(20 \mathrm{~mL})$ acidified with acetic acid to $\mathrm{pH}=3.8$ is added, and the solution is extracted with a portion of dichloromethane $(20 \mathrm{~mL})$. The acidic solution is decolourized with $1 \mathrm{~g}$ of activated carbon and alkalinized to $\mathrm{pH}=10.0$ with a $12 \%$ ammonium hydroxide solution, then it is extracted twice with ethyl acetate $(15 \mathrm{~mL})$, washed with brine and dried over sodium sulfate. The organic solution is treated with ethyl acetate saturated with oxalate at $0-5{ }^{\circ} \mathrm{C}$. The phenoxypropylamine derivatives oxalate 6a-6f are obtain as white precipitates [3].

$N$-\{3-[3-(1-Piperidinylmethyl)phenoxy] propyl\}methylaminoacetamide oxalate (6a): yield 62.8\%; m.p. 132-134 ${ }^{\circ} \mathrm{C} ;{ }^{1} \mathrm{H}-\mathrm{NMR} \delta: 1.41-1.43(\mathrm{~d}, 2 \mathrm{H}, J=5), 1.53-1.60(\mathrm{~m}, 4 \mathrm{H}, J=5), 1.98(\mathrm{t}, 2 \mathrm{H}), 2.01-2.09$ (m, 2H, J=7), $2.37(\mathrm{~s}, 4 \mathrm{H}), 2.54(\mathrm{~s}, 1 \mathrm{H}), 3.44(\mathrm{~s}, 4 \mathrm{H}), 3.51-3.57(\mathrm{~m}, 2 \mathrm{H}, J=7), 4.06(\mathrm{~s}, 2 \mathrm{H}), 4.07-4.11(\mathrm{t}$, $2 \mathrm{H}, J=7), 6.77-6.80(\mathrm{dd}, 1 \mathrm{H}, J=8), 6.90-6.92(\mathrm{~d}, 2 \mathrm{H}, J=8), 7.19-7.24(\mathrm{t}, 1 \mathrm{H}, J=8)$; Elemental anal. calcd. (\%) for $\mathrm{C}_{18} \mathrm{O}_{2} \mathrm{~N}_{3} \mathrm{H}_{29}$ : C, 67.68; H, 9.15; N, 13.15. Found (\%): C, 67.48; H,9.20; N, 11.40. MS $\mathrm{m} / \mathrm{z}$ (ESI): calcd. for $\mathrm{C}_{18} \mathrm{O}_{2} \mathrm{~N}_{3} \mathrm{H}_{29}[\mathrm{M}+\mathrm{H}] 320.45$, found 320.30 .

$N$-\{3-[3-(1-piperidinylmethyl)phenoxy]propyl $\}$ isopropylaminoacetamide oxalate (6b): yield 47.8\%; m.p. $169-171^{\circ} \mathrm{C} ;{ }^{1} \mathrm{H}-\mathrm{NMR} \delta: 0.85(\mathrm{t}, 3 \mathrm{H}), 1.26(\mathrm{~m}, 2 \mathrm{H}), 1.42-1.44(\mathrm{~d}, 2 \mathrm{H}, J=5), 1.52-1.61$ (m, 4H, $J=5), 1.93$ (s, 1H), 2.01-2.09 (m, 2H, $J=7), 2.39$ (s, 4H), 2.87 (m, 4H), $3.45(\mathrm{~s}, 2 \mathrm{H}), 3.52-.358(\mathrm{~m}, 2 \mathrm{H}$, $J=7), 4.08$ (s,2H), 4.09-4.13 (t, 2H, $J=7), 4.10$ (s, 1H), 6.97-6.99 (dd, 1H, J=8), 7.02-7.12 (d, 2H, J=8), 7.20-7.26 (t, $1 \mathrm{H}, J=8)$; Elemental anal. calcd. (\%) for $\mathrm{C}_{21} \mathrm{O}_{2} \mathrm{~N}_{3} \mathrm{H}_{35}: \mathrm{C}, 69.77 ; \mathrm{H}, 9.76 ; \mathrm{N}, 11.62$. Found (\%): C, 69.52; H,9.80; N, 11.60. MS m/z (ESI): calcd. for $\mathrm{C}_{21} \mathrm{O}_{2} \mathrm{~N}_{3} \mathrm{H}_{35}[\mathrm{M}+\mathrm{H}]$ 362.54, found 362.30 .

$N$-\{3-[3-(1-Piperidinylmethyl)phenoxy]propyl\}n-butylaminoacetamide oxalate (6c): yield 47.8\%; m.p. 158-160 ${ }^{\circ}$ C. ${ }^{1} \mathrm{H}-\mathrm{NMR} \delta: 0.95(\mathrm{t}, 6 \mathrm{H}), 1.26(\mathrm{~m}, 2 \mathrm{H}), 1.42-1.44(\mathrm{~d}, 2 \mathrm{H}, J=5), 1.52-1.61$ (m, 2H, J=5), $1.93(\mathrm{~s}, 1 \mathrm{H}), 2.01-2.09(\mathrm{~m}, 2 \mathrm{H}, J=7), 2.39(\mathrm{~s}, 2 \mathrm{H}), 2.87(\mathrm{~m}, 3 \mathrm{H}), 3.45(\mathrm{~s}, 2 \mathrm{H}), 3.52-.3 .58(\mathrm{~m}, 2 \mathrm{H}, J=7)$, 4.08 (s, 2H), 4.09-4.13 (t, 2H, J=7), 4.10 (s, 1H), 6.97-6.99 (dd,1H, J=8), 7.02-7.12 (d, 2H, J=8), 7.20- 
7.26 (t, 1H, J=8); Elemental anal. calcd. (\%) for $\mathrm{C}_{21} \mathrm{O}_{2} \mathrm{~N}_{3} \mathrm{H}_{35}: \mathrm{C}, 66.44 ; \mathrm{H}, 9.20 ; \mathrm{N}, 11.62$. Found (\%): C, 69.80; H,9.82; N, 11.59. MS m/z (ESI): calcd. for $\mathrm{C}_{20} \mathrm{O}_{2} \mathrm{~N}_{3} \mathrm{H}_{33}[\mathrm{M}+\mathrm{H}] 348.50$, found 348.30.

$N$-\{3-[3-(1-Piperidinylmethyl)phenoxy]propyl\}tertiary-butylaminoacetamide oxalate (6d): yield 76.4\%; m.p. $129-131{ }^{\circ} \mathrm{C}$ (from ethanol); ${ }^{1} \mathrm{H}-\mathrm{NMR}$ : 1.26 (m, 9H), 1.46-1.48 (s, 2H, J=5), 1.52-1.64 (s, 4H, J=5), 1.99 (s, 2H), 2.96 (s, 4H), 3.45 (s, 2H), 3.52-3.58 (m, 2H, J=7), 4.09 (s, 3H), 4.10-4.14 (t, $2 \mathrm{H}, J=7), 6.93-6.98(\mathrm{dd}, 1 \mathrm{H}, J=8), 7.04-7.30(\mathrm{~d}, 2 \mathrm{H}, J=8), 7.18-7.25(\mathrm{t}, 1 \mathrm{H}, J=8), 8.8(\mathrm{~s}, 1 \mathrm{H})$; Elemental anal. calcd. (\%) for $\mathrm{C}_{21} \mathrm{O}_{2} \mathrm{~N}_{3} \mathrm{H}_{35}$ : C, 69.77; H, 9.76; N, 11.62. Found (\%): C, 69.62; H, 9.80; $\mathrm{N}, 11.39 ; \mathrm{MS} \mathrm{m} / \mathrm{z}$ (ESI): calcd. for $\mathrm{C}_{21} \mathrm{O}_{2} \mathrm{~N}_{3} \mathrm{H}_{35}[\mathrm{M}+\mathrm{H}]$ 362.54, found 362.40 .

$N$-\{3-[3-(1-Piperidinylmethyl)phenoxy]propyl\}cyclopentyaminoacetamide oxalate (6e): yield 48.3\%; m.p. $162-164^{\circ} \mathrm{C}$ (from ethanol); ${ }^{1} \mathrm{H}-\mathrm{NMR}$ : 1.42-1.43 (d, 2H, J=5), $1.48(\mathrm{~m}, 4 \mathrm{H}), 1.56(\mathrm{~m}, 4 \mathrm{H}, J=5)$, $1.91(\mathrm{~s}, 3 \mathrm{H}), 2.01-2.09$ (m, 4H, J=7), $2.38(\mathrm{~s}, 4 \mathrm{H}), 3.44(\mathrm{~s}, 4 \mathrm{H}), 3.57$ (m, 2H, J=7), 4.06 (s, 2H), 4.07$4.11(\mathrm{t}, 2 \mathrm{H}, J=7), 6.77-6.80(\mathrm{dd}, 1 \mathrm{H}, J=8), 6.90-6.92$ (d, 2H, $J=8), 7.19-7.24$ (t, 1H, $J=8)$; Elemental anal. calcd. (\%) for $\mathrm{C}_{22} \mathrm{O}_{2} \mathrm{~N}_{3} \mathrm{H}_{35}$ : C, 70.74; $\mathrm{H}, 9.44 ; \mathrm{N}, 11.25$. Found (\%): C, 70.54; H, 9.81; N, 11.32; MS m/z (ESI): calcd. for $\mathrm{C}_{22} \mathrm{O}_{2} \mathrm{~N}_{3} \mathrm{H}_{35}[\mathrm{M}+\mathrm{H}] 374.55$, found 374.00 .

$N$-\{3-[3-(1-Piperidinylmethyl)phenoxy]propyl\}cyclohexylaminoacetamide oxalate (6f): yield 51.1\%; m.p. $160-162^{\circ} \mathrm{C}$ (from ethanol); ${ }^{1} \mathrm{H}-\mathrm{NMR}: 1.42-1.43(\mathrm{~d}, 2 \mathrm{H}, J=5), 1.48(\mathrm{~m}, 4 \mathrm{H}), 1.56(\mathrm{~m}, 4 \mathrm{H}, J=5)$, 1.91 (s, 3H), 2.01-2.09 (m, 4H, J=7), 2.38 (s, $4 \mathrm{H}), 3.44$ (m, 6H), 3.57 (m, 2H, J=7), 4.06 (s, 2H), 4.074.11 (t, 2H, J=7), 6.77-6.80 (dd, $1 \mathrm{H}, J=8), 6.90-6.92$ (d, 2H, $J=8), 7.19-7.24$ (t, 1H, J=8); Elemental anal. calcd. (\%) for $\mathrm{C}_{23} \mathrm{O}_{2} \mathrm{~N}_{3} \mathrm{H}_{37}$ : C,71.28; H, 9.62; N, 10.84. Found (\%): C, 71.18; H, 9.32; N, 10.69. MS m/z (ESI): calcd. for $\mathrm{C}_{23} \mathrm{O}_{2} \mathrm{~N}_{3} \mathrm{H}_{37}[\mathrm{M}+\mathrm{H}] 388.56$, found 388.00.

\section{Acknowledgements}

We are grateful for financial support from the Education Department of Liaoning Province, P.R. China (Project No. 20060885).

\section{References and Notes}

1. Nakamura, K.; Kariyazono, H.; Shinkawa, T.; Yamaguchi, T.; Yamashita, T.; Ayukawa, O.; Moriyama, Y.; Yotsumoto, G.; Toyohira, H.; Taira, A.; Yamada, K. Inhibitory effects of $\mathrm{H}_{2-}$ receptor antagonists on platelet function in vitro. Hum. Exp. Toxicol. 1999, 18, 487-492.

2. Tarpanov, V.; Vlahov, R.; Penkov, M.; Krikorian, D.; Parushev, S.; Mechkarova, P.; Angelova, N.; Schunack, W. A new synthesis of roxatidine acetate. Syn. Commun. 1999, 29, 15-20.

3. Ueda, K.; Ishii, K.; Shinozaki, K.; Seiki, M.; Arai, H.; Hatanaka, M. Synthesis and Pharmacological properties of N-\{3-[3-(1-piperidinymethyl)phenoxy]propyl\}-2-(2-hydroxyethylthio)acetimide and related compounds as antiulcer agents. J. Chem. Pharm. Bull. 1990, 38, 30353041 .

4. Schulze, F.R.; Buschauer, A.; Schunack, W. Combined histamine $\mathrm{H}_{1} / \mathrm{H}_{2}$ receptor antagonists: Part I. Pharmacological hybrids with pheniramine- and roxatidine-like substructures. Eur. J. Pharm. Sci. 1998, 6, 177-186. 
5. Murdoch, D.; McTavish, D. Roxatidine acetate. A review of its pharmacodynamic and pharmacokinetic properties, and its therapeutic potential in peptic ulcer disease and related disorders. Drugs 1991, 42, 240-260.

6. Sekine, Y.; Hirakawa, N.; Kashiwaba, N.; Matsumoto, H.; Kutsuma, T.; Yamaura, T.; Sekine, A. A novel histamine $2\left(\mathrm{H}_{2}\right)$ receptor antagonist with gastro protective activity. I. Synthesis and pharmacological evaluation of $\mathrm{N}$-phenoxypropylacetamide derivatives with thioether function. Chem. Pharm. Bull. (Tokyo) 1998, 46, 610-615.

7. Larsson, H.; Carlsson, E.; Sundell, G. Effects of Omeprazole and Cimetidine on Gastric Acid Secretion an right atrial beating frequancy in isolated organ preparations from the guinea pig. Digestion, 1984, 29, 12-18.

Sample Availability: Contact the authors.

(C) 2009 by the authors; licensee Molecular Diversity Preservation International, Basel, Switzerland. This article is an open-access article distributed under the terms and conditions of the Creative Commons Attribution license (http://creativecommons.org/licenses/by/3.0/). 